\title{
Do current times vindicate Keynes and is New Keynesian macroeconomics Keynesian?
}

\author{
Thomas I. Palley \\ Independent analyst, Washington, DC, USA
}

\section{Esteban Pérez Caldentey}

Chief, Financing for Development Unit, Economic Development Division, Economic Commission for Latin America and the Caribbean, Santiago, Chile

Matías Vernengo

Professor, Bucknell University, Lewisburg, PA, USA

Professor Robert Rowthorn delivered the second annual Godley-Tobin lecture in New York City on 1 March 2019. The title of his lecture was 'Keynesian economics back from the dead?' and it is published in this issue of the Review of Keynesian Economics. The lecture was attended by a large audience and the Question \& Answer session provoked a stimulating discussion. Prompted by that discussion, we thought it would be interesting to invite some leading economists to independently address Professor Rowthorn's lecture topic. This symposium is the outcome of that invitation.

We are living in a time which many believe has a distinctly Keynesian character. That is captured in the belief that many economies appear to suffer from aggregate demand shortage or, at least, a proclivity to demand shortage. It is also captured in the revival of the concept of 'economic stagnation,' which was an idea that had much traction in the 1930s and 1940s but then fell away in the 1950s with the postwar boom and the non-reappearance of depression-like conditions.

Another Keynesian feature of the times is the character of macroeconomic policy, particularly fiscal policy. Following the financial crisis of 2008 and the Great Recession it spawned, there was a global turn to sizeable coordinated fiscal stimulus. Though that turn was truncated (Keynesians would say mistakenly), its legacy remains in place in the sense that discretionary counter-cyclical fiscal policy is back. That is evident in the renewed widespread belief among economists and policymakers regarding the value of fiscal stimulus to combat recessions, though the details of when, how, and how much are still contested. That contrasts with the situation before the Great Recession when the mainstream consensus was that discretionary counter-cyclical fiscal policy was largely ineffective.

Likewise, activist monetary policy is back. The Keynesian approach to monetary policy never suffered quite the same eclipse as fiscal policy, but it still suffered. First came the attacks of Monetarists who recommended money-supply targeting and a money-supply growth rule. That was then replaced by the 'Taylor rule' approach which recommends counter-cyclical interest-rate targeting, but relies on a fixed rule for doing so. Now, in the wake of the financial crisis, the 'rules' approach to interest-rate policy has given way to 'discretion.' Furthermore, there has been a shift in favor of quantitative monetary policy, which had been essentially exiled since the mid 1970s. 
In response to those developments, mainstream economic theory has not stood still. Instead, it has built upon the approach known as 'New Keynesian' macroeconomics. That approach surfaced in the late 1970s. It adds nominal frictions (for example, longterm nominal contracts and price adjustment 'menu' costs) to the New Classical macroeconomic model to explain the non-neutrality of money and to deliver more persistent unemployment in response to monetary disturbances.

In the wake of the Great Recession, New Keynesians have added two features that ramp up the 'Keynesian' appearance. First, they have added the zero lower bound (ZLB) to nominal interest rates, which is the latest nominal rigidity. That can block the real-interest rate from falling to the level needed to ensure aggregate demand is equal to full employment output. Second, they are abandoning Friedman's (1957) permanent income theory of consumption, with its assumption of a common propensity to consume. In its place, they are borrowing from heterodox Keynesian consumption theory, which emphasizes higher-income households have a lower marginal propensity to consume. That makes income distribution and debt important for saving and aggregate demand, which can then bring the ZLB problem into play.

To us, Professor Rowthorn's lecture prompts two fundamental questions. First, are current times Keynesian and do they vindicate the fundamental correctness of Keynes's General Theory (1936)? Second, is New Keynesian macroeconomics Keynesian, or is it based on a different economic theory with the aim of mimicking outcomes which Keynes and 'old' Keynesians identified and sought to explain? We hope this symposium encourages dialogue between the New Keynesian mainstream and Keynesians outside the mainstream, on both those and other questions.

\section{REFERENCES}

Friedman, M. (1957), A Theory of the Consumption Function, Princeton, NJ: Princeton University Press for National Bureau of Economic Research.

Keynes, J.M. (1936), The General Theory of Employment, Interest, and Money, London: Macmillan. 